\title{
Dietary Characteristics of Eastern James Bay Cree Women
}

\author{
TREENA DELORMIER ${ }^{1}$ and HARRIET V. KUHNLEIN ${ }^{1}$
}

\author{
(Received 10 June 1997; accepted in revised form 29 October 1998)
}

\begin{abstract}
Food use and nutrient intake were studied with Cree women of Wemindji and Eastmain, Quebec. During summer 1994 and winter 1995, 24-hour recalls and food frequency questionnaires were collected from 219 women of three age groups (20-40; 41-60; >60 years). While reported energy intakes were somewhat low, $94 \%$ of the women exceeded $2 / 3$ of the recommended nutrient intake (RNI) for protein, and $80 \%$ exceeded $2 / 3$ of the RNI for iron. However, $44 \%$ of the women reported calcium intakes of less than $1 / 2$ the RNI. Mean total fat intake reported by young and middle adults was greater than $30 \%$ of total energy. Primary sources of fat were market food, indicating that education efforts targeting fat intake should emphasize market food choices. Species and amounts of traditional food consumed varied by season. The percentage of elders who consumed traditional food was significantly higher $\left(p<0.001, \chi^{2}=29\right.$, Mantel-Haenzel $)$ than those of traditional food users in the middle and younger age groups. Dietary data for the James Bay Cree, which were lacking prior to this research, are important resources for those working in health and wellness with this population group and other aboriginal groups that use traditional food.
\end{abstract}

Key words: Eastern James Bay Cree, nutrient intake, food use, traditional food, Subarctic, indigenous people

RÉSUMÉ. On a étudié l'utilisation de la nourriture et l'apport nutritif chez des femmes cris de Wemindji et de Eastmain au Québec. Durant l'été de 1994 et l'hiver de 1995, on a recueilli des rappels de 24 heures sur les aliments et des questionnaires portant sur la fréquence de consommation de certains aliments auprès de 219 femmes appartenant à trois groupes d'âge $(20$ à 40,41 à 60 et $>60$ ans). Alors que les apports en énergie mentionnés étaient plutôt bas, 94 p. cent des femmes dépassaient les deux tiers de l'apport nutritionnel recommandé (ANR) en protéines, et 80 p. cent dépassaient les deux tiers de l'ANR en fer. Cependant, 44 p. cent des femmes ont déclaré des apports de calcium inférieurs à la moitié de l'ANR. La moyenne de l'apport total en gras rapporté par les jeunes adultes et les adultes d'âge moyen était supérieure à $30 \mathrm{p}$. cent de l'énergie totale. Les principales sources de gras étaient les aliments provenant du marché, ce qui révèle que les efforts en vue d'éduquer les consommateurs sur l'apport en gras devraient insister sur les choix qui s'offrent dans les aliments disponibles au marché. Les espèces et les quantités d'aliments traditionnels consommés variaient avec les saisons. Le pourcentage d'anciens qui consommaient la nourriture traditionnelle était sensiblement supérieur ( $p<0,001, \chi^{2}=29$, Mantel-Haenszel) à celui des utilisateurs d'aliments traditionnels situés dans le groupe des jeunes adultes et celui des adultes d'âge moyen. Les données alimentaires pour les Cris de la Baie James, inexistantes avant ces recherches, constituent d'importantes ressources pour les personnes travaillant en santé et mieux-être avec ce groupe de population et d'autres groupes autochtones qui utilisent des aliments traditionnels.

Mots clés: Cri de la Baie James orientale, apport nutritionnel, utilisation de la nourriture, aliments traditionnels, Subarctique, peuple autochtone

Traduit pour la revue Arctic par Nésida Loyer.

\section{INTRODUCTION}

The Eastern James Bay Cree have experienced relatively recent changes in lifestyle due to sociocultural, political, and environmental factors. These changes have affected diet, traditional food use, and nutrition. The extent to which diet has changed has scarcely been examined; however, the role of diet in observed patterns of health and disease has been recognized (Thouez et al., 1989; Young, 1994). Of particular concern are the decreased use of traditional food by children and the younger generation, changes in patterns of fish consumption arising from public health efforts related to methylmercury contamination, and increased prevalence of chronic conditions such as obesity, diabetes, and cardiovascular disease. Central to these issues are questions about the current diet and food consumption patterns of the Cree.

Traditionally the diet consisted of fish, large and small game, a variety of waterfowl, and plant food from the local environment (Schaefer, 1977). Today the diet includes both these traditional food items and market foods. All communities have access to at least one grocery store. Hunting and trapping is still a way of life for at least $1 / 3$ of the population, and more are involved with hunting and trapping on a part-time basis. Traditional food holds a

${ }^{1}$ Centre for Indigenous Peoples' Nutrition and Environment, and School of Dietetics and Human Nutrition, Macdonald Campus of McGill University, 21111 Lakeshore Road, Ste. Anne de Bellevue, Quebec H9X 3V9, Canada; kuhnlein@agradm.lan.mcgill.ca

(C) The Arctic Institute of North America 
strong cultural identity for the Cree. This is reflected in all aspects of its use from hunting and trapping to food sharing, feasts, and food preparation (Delormier, 1993).

Some researchers have examined the potential nutrient content of the diet through inventory and harvest studies (Farkas and Berkes, 1978; James Bay Northern Quebec Native Harvesting Research Committee, 1982). However, few have examined dietary intake (Bernard and Lavallée, 1993; Bernard et al., 1995) and none have examined factors that influence the use of traditional food.

The present dietary research examined nutrient intake and traditional food use among three generations of adult women from two Cree communities during one summer and one winter season.

\section{METHODS}

Approval for the research proposal was obtained from the Human Ethics Review Committee of Macdonald Campus, McGill University. To meet these requirements, a research agreement was signed between those responsible for the research and the communities involved in the research, through a band council representative. Each participant signed an informed consent form before taking part in the interviews.

Preliminary work carried out in the communities used qualitative methods: key-informant interviewing, focus groups, and participant observation. This community input ensured that the design and objectives of the study were relevant to the communities' food use.

Adult women from Wemindji and elder women from Eastmain were randomly selected from registers for health and social services to participate in the study. Of the 219 women interviewed, 89 were $20-40$ years old; 82 were $40-60$ years old; and 48 were more than 60 years old. The women from Eastmain, a community that shares similar characteristics with Wemindji, were included to increase the number of elders. Of the total who were invited to participate, fewer than $10 \%$ refused. Women were asked to participate because of the significant role they play in selecting and preparing food for the family. Women's nutritional needs are difficult to meet because the need for certain nutrients (e.g., iron) changes as women age, and so do their energy requirements.

Data collection periods (July 1994 and January 1995) reflected two seasons and were selected on the advice of community members to demonstrate seasonal differences in food use.

The dietary interview consisted of a 24-hour recall and questionnaires on traditional food frequency and dietary change. The 24-hour recall required the individual to state the types and quantity of all foods and beverages taken in the previous 24-hour period. Food portion sizes were estimated using a bowl, a cup, and household measuring cups and spoons. The questionnaire asked individuals to recall the frequency with which they ate listed traditional
TABLE 1 . Mean daily energy and nutrient intake (Mean \pm SD) by age group and season (data from 24-hour recall interviews).

\begin{tabular}{lrrr}
\hline \hline Nutrient & $\begin{array}{c}20-40 \text { Years } \\
(\mathrm{n}=89)\end{array}$ & $\begin{array}{c}41-60 \text { Years } \\
(\mathrm{n}=82)\end{array}$ & $\begin{array}{c}\text { Over 60 Years } \\
(\mathrm{n}=48)\end{array}$ \\
\hline Energy, kcal & $1897 \pm 763$ & $1730 \pm 713$ & $1312 \pm 654$ \\
Carbohydrate, g & $200 \pm 85$ & $154 \pm 73$ & $110 \pm 66$ \\
Protein, g & $94 \pm 56$ & $110 \pm 61$ & $108 \pm 63$ \\
Fat, g & $80 \pm 42$ & $73 \pm 38$ & $47 \pm 34$ \\
Iron, mg & $16 \pm 10$ & $17 \pm 11$ & $13 \pm 8$ \\
Calcium, mg & $482 \pm 289$ & $520 \pm 367$ & $390 \pm 315$ \\
\hline \hline
\end{tabular}

food items. The food frequency questionnaire, developed from interviews and observations in the communities and validated with community members in focus groups, listed 29 species of wildlife, each with 2 to 11 edible parts. A final portion of the interview was composed of open-ended questions investigating the changing diet. Community members fluent in the Cree language (the first language in these communities) conducted the interviews. Interviewers were trained in dietary interviewing techniques by one of the investigators (TD). This method has been used successfully in other Canadian aboriginal dietary studies (Wein et al., 1991, 1993; Campbell et al., 1994b; Kuhnlein, 1995; Kuhnlein et al., 1995).

For nutrient analysis of the Cree diet, we used published data on the composition of traditional foods. For important Cree foods not described in published sources, we determined the nutrient content and added that information to the traditional food database. Market food items were analyzed using the University of California, Berkeley mini list (Murphy, 1989), which was considered appropriate for market food used by the Cree. The traditional food database was merged with the market food database to complete the diet analysis.

The food codes and weights of food items from the 24hour recall and the food frequency information were entered into the Epi-Info software (Dean et al., 1994). All statistical analysis was performed using PC-SAS statistical software (SAS Institute Inc., 1989).

\section{RESULTS}

Table 1 shows the mean daily energy and nutrient intake by age group, calculated from the recall data. Energy intakes appear to be low, particularly for the over 60 age group. Evaluation of the adequacy of reported nutrient intakes is shown in Figure 1. Comparison of individual intakes of nutrients to recommended nutrient intakes showed that more than $50 \%$ of the women had energy intakes greater than $2 / 3$ the RNI.

\section{Nutrient Intake}

We evaluated individual intakes of nutrients for which RNIs exist, using the same method used to evaluate energy 


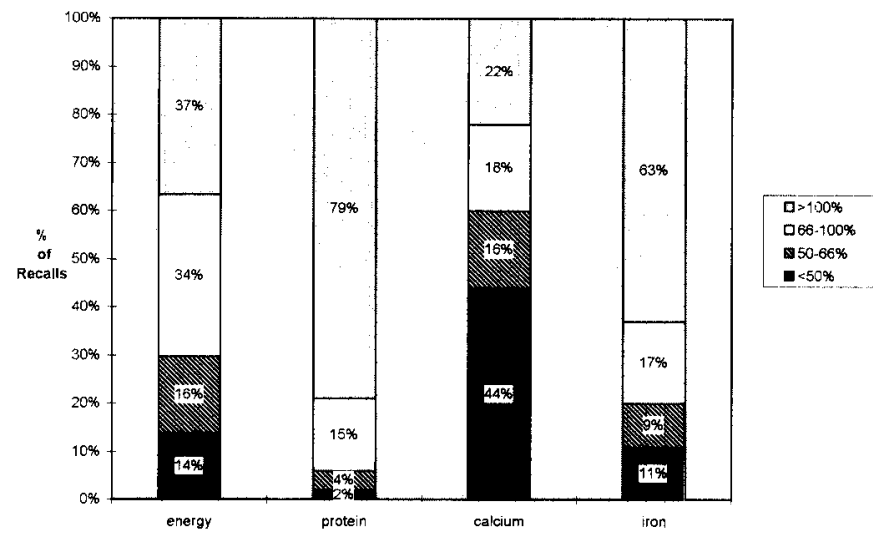

FIG. 1. Percentage of recalls in Recommended Nutrient Intake (RNI) categories ( $\mathrm{n}=219,24$-hour recalls). RNI categories from Health and Welfare Canada (1990).

intakes. For protein, we found that $94 \%$ of women reported intakes greater than $2 / 3$ of the RNI, while only $2 \%$ reported intakes of less than $1 / 2$ of the RNI. For iron, $80 \%$ of women reported intakes greater than $2 / 3$ of the RNI, and $63 \%$ reported intakes that exceeded the RNI. For calcium, $44 \%$ of reported intakes fell below $1 / 2$ of the RNI levels, and $40 \%$ were above $2 / 3$ of the RNI. For carbohydrate, no RNIs exist; however, it is recommended for the general Canadian population to obtain $55 \%$ of energy from carbohydrate (Health and Welfare Canada, 1990). In our study, the mean percentage of energy from carbohydrate reported was $43 \pm 11 \%$ for the youngest age group, $37 \pm 13 \%$ for the middle group, and $35 \pm 15 \%$ for the eldest group.

\section{Dietary Fat Intake}

It was of interest to look specifically at fat intake and sources of fat in the diet. Anecdotal evidence suggested that some Cree were consuming too much fat. The mean percentage of fat as total energy was $37 \pm 9 \%, 37 \pm 9 \%$, and $30 \pm 11 \%$ of total energy for young, middle, and elder women, respectively.

Examining the food sources of fat revealed that very few traditional foods are important sources of total fat (Table 2). In the winter (January 1995), the top 20 sources of fat included only one traditional food, Canada goose, which provided $3.4 \%$ of total fat. The top source of fat was French fries (9.6\% of total fat). In the summer (July 1994), Canada goose was the most important source of fat, furnishing $14.3 \%$ of total fat. Ranked sources of fat were calculated by adding total fat from individual food items reported by all women and expressing the sum as a percentage of total fat reported by all women.

\section{Dietary Fat Intake from Traditional Food and Market Food}

The following analyses used data from women who reported using both traditional and market food on 24-hour recalls. The mean percentage of fat from market food was
TABLE 2. Top 20 sources of fat, from all 24-hour recalls.

\begin{tabular}{|c|c|c|c|c|}
\hline \multirow[b]{2}{*}{ Rank } & \multicolumn{2}{|l|}{ Winter ${ }^{1} 1995(\mathrm{n}=87)$} & \multicolumn{2}{|c|}{ Summer $^{2} 1994(n=132)$} \\
\hline & Food & $\begin{array}{l}\% \text { of total } \\
\text { fat intake }\end{array}$ & Food & $\begin{array}{l}\% \text { of total } \\
\text { fat intake }\end{array}$ \\
\hline 1 & french fries & 9.6 & Canada goose & 14.3 \\
\hline 2 & margarine & 6.8 & lard & 6.5 \\
\hline 3 & bannock & 6.6 & margarine & 5.8 \\
\hline 4 & eggs & 6.1 & french fries & 5.4 \\
\hline 5 & ground beef, regular & 5.9 & eggs & 5.4 \\
\hline 6 & beef, $30 \%$ fat & 5.7 & bannock & 5.1 \\
\hline 7 & chicken & 4.5 & ground beef, regular & 4.9 \\
\hline 8 & frankfurters, lunch meat & 4.4 & chicken & 4.1 \\
\hline 9 & macaroni and cheese & 4.3 & whitefish, smoked & 3.8 \\
\hline 10 & lard & 3.7 & canola oil & 3.3 \\
\hline 11 & Canada goose & 3.4 & frankfurters, lunch meat & 3.3 \\
\hline 12 & canola oil & 3.3 & goose grease & 2.7 \\
\hline 13 & pork chop, pork, lean & 2.6 & pork chop, pork, lean & 2.3 \\
\hline 14 & milk $2 \%$ & 2.6 & milk $2 \%$ & 2.3 \\
\hline 15 & bacon & 2.5 & whitefish & 2.2 \\
\hline 16 & bread, white, enriched & 2.5 & bread, white, enriched & 1.9 \\
\hline 17 & potatoes & 1.6 & salad dressing, mayo-type & pe 1.7 \\
\hline 18 & salad dressing, mayo-type & 1.6 & potatoes & 1.6 \\
\hline 19 & butter & 1.6 & butter & 1.6 \\
\hline 20 & pizza, frozen, mix, cheese & 1.5 & corned beef, canned & 1.4 \\
\hline
\end{tabular}

${ }^{1}$ Winter 1995: mid-January to mid-February

${ }^{2}$ Summer 1994: July

TABLE 3. Mean percent of fat (Mean \pm SD) from market and traditional food sources in the diet of 132 women who reported both food sources.

\begin{tabular}{lccc}
\hline \hline Source and Season & 20-40 years & $40-60$ years & Over 60 years \\
\hline Winter 1995: & $\mathrm{n}=10$ & $\mathrm{n}=21$ & $\mathrm{n}=14$ \\
$\quad$ Market source & $80 \pm 17$ & $82 \pm 14$ & $78 \pm 17$ \\
$\quad$ Traditional source & $20 \pm 17$ & $18 \pm 14$ & $22 \pm 17$ \\
& & & \\
Summer 1994: & $\mathrm{n}=24$ & $\mathrm{n}=38$ & $\mathrm{n}=25$ \\
$\quad$ Market source & $64 \pm 20$ & $63 \pm 27$ & $47 \pm 28$ \\
$\quad$ Traditional source & $36 \pm 20$ & $37 \pm 27$ & $53 \pm 28$ \\
\hline \hline
\end{tabular}

higher in the winter season for all age groups, approximately $20 \%$ higher for young and middle adults, and $30 \%$ higher for elders (Table 3 ). The women obtained a greater proportion of their fat intake from traditional foods in summer than in winter. In the summer, when more traditional food was consumed, the elder adult women obtained about $1 / 2$ of their total fat from traditional sources. For the young adults and middle adults, traditional foods provided only about $1 / 3$ of total dietary fat.

\section{Seasonal Use of Traditional Food}

Figure 2 shows seasonal differences in the amounts of each food consumed, from the 24-hour recall data. Each species was categorized as fish, bird, small mammal, or large mammal. For each category, the weights of all food species were totalled. These totals were used to calculate the portion of total traditional food weight represented by each category. The summer diet emphasized fish and bird species, while the winter diet included more large and 


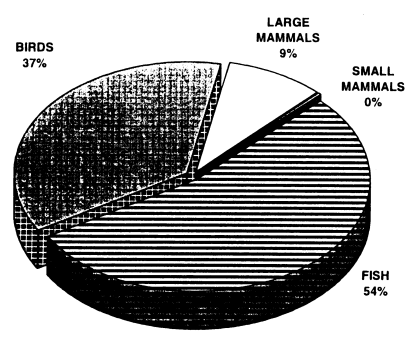

Summer 1994 $\mathrm{n}=132$

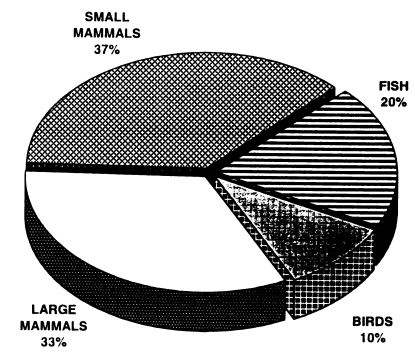

Winter 1995 $n=87$
FIG. 2. Percent of total traditional food weight contributed by each traditional food category, by season.

small mammals. No traditional plant foods were reported on 24-hour recalls.

The food frequency interview data (not shown) also showed seasonal differences in traditional food consumption. For the spring period (April-June 1994), the three most frequently consumed traditional foods were Canada goose flesh (3.2 \pm 2.1 times/wk), whitefish flesh (1.4 \pm 1.7 times/wk), and Canada goose heart (1.2 \pm 1.9 times/wk). For the fall period (October-December 1994), the three most consumed traditional foods were rabbit flesh (2.2 \pm 2.1 times/wk), moose flesh (1.4 \pm 1.9 times/wk), and beaver flesh $(1.4 \pm 1.7$ times/wk).

\section{Age Difference in the Number of Women Who Consume Traditional Food}

Research with Cree and other northern aboriginal peoples has demonstrated differential use of traditional food according to age. The trend observed is that elders, in general, eat more traditional food. From the 24-hour recall interview data, we examined the number of women who ate traditional food and market food. Reported consumers of traditional food are shown in Table 4. There was a statistically significant association between age and the number of consumers of traditional food $(p<0.001)$. Elders had the greatest proportion of traditional food users, followed by the middle adult group and then the young adult group.

\section{DISCUSSION}

Low energy intakes are of concern in dietary studies primarily because they may reflect low nutrient intakes. But low intakes may also result from incomplete dietary recalls or may indicate systematic or general underreporting of food items. Self-reported dietary intakes tend to underestimate food consumption for individuals (Mertz et al., 1991; Black et al., 1993) and a variety of sample age groups (Bingham and Nelson, 1991).

Overweight persons may tend to underreport food intakes (Anderson, 1986). A recent health survey found that $29.8 \%$ of Cree women were overweight, with body mass
TABLE 4. Number and percentage of women who consumed traditional food, by season and age group.

\begin{tabular}{|c|c|c|}
\hline Age Group (years) & $\begin{array}{l}\text { No. of traditional } \\
\text { food consumers }(\%)^{1}\end{array}$ & $\begin{array}{l}\text { No. of market food } \\
\text { consumers }(\%)^{2}\end{array}$ \\
\hline \multicolumn{3}{|l|}{ Summer 1994} \\
\hline $20-40(\mathrm{n}=53)$ & $24(45)^{3}$ & $29(55)$ \\
\hline $40-60(n=49)$ & $38(78)^{3}$ & $11(22)$ \\
\hline Over $60(n=30)$ & $25(83)^{3}$ & $5(17)$ \\
\hline \multicolumn{3}{|l|}{ Winter 1995} \\
\hline $20-40(n=36)$ & $10(28)^{3}$ & $26(72)$ \\
\hline $40-60(\mathrm{n}=33)$ & $21(64)^{3}$ & $12(36)$ \\
\hline Over $60(\mathrm{n}=18)$ & $14(78)^{3}$ & $4(22)$ \\
\hline \multicolumn{3}{|c|}{${ }^{1}$ Refers to women who reported traditional food. } \\
\hline \multicolumn{3}{|c|}{${ }^{2}$ Refers to women who reported only market food. } \\
\hline \multicolumn{3}{|c|}{${ }^{3}$ Significant association between age group and number of womer } \\
\hline
\end{tabular}

index (BMI) between 25 and 29.99, and 56.9\% were obese, with BMI greater than 30 (Daveluy et al., 1994). The low intakes may be explained in part by an underreporting bias of this sort.

There are neither reported energy intakes of Cree adult women nor recent Canadian intake data to compare with this data set. However, except for the over-60 age group, our intakes compare closely to those of the American Third National Health and Nutrition Examination, known as NHANES III (McDowell et al., 1994). It is not possible to assess the adequacy of energy intakes from dietary intake data alone, without information on energy expenditure or anthropometric measurements.

RNIs for nutrients have been set at levels to meet the needs of most people in a characteristic group. Therefore, an intake corresponding to $100 \%$ of the RNI exceeds the actual needs of most individuals. An arbitrary proportion of $2 / 3$ of the RNI is often used as a cutoff to gain an understanding of the proportion of individuals who may be at risk of inadequate intake. This is done to describe the population profile, not to identify individuals who are deficient in nutrient intakes.

For protein, the mean intakes reported here were consistently higher than those reported in other studies of Arctic and Subarctic women (Sevenhuysen and BogertO'Brien, 1987; Wein et al., 1991, 1993; Campbell et al., 1994a; Wein, 1995), except that Kuhnlein et al. (1995) reported mean protein intakes of $143 \pm 87 \mathrm{~g}$ for Sahtú Dene/Métis women 20-40 years of age. This comparison with other studies, the fact that $94 \%$ of women exceeded the $2 / 3$ RNI cutoff, and examination of the protein sources reported on the recalls all indicate that reported protein intakes are probably adequate.

For iron, $80 \%$ of adult women reported intakes that exceeded $2 / 3$ RNI. Like the protein intakes, iron intakes reported in this study are higher than those reported in other Arctic and Subarctic dietary research (except for Kuhnlein et al., 1995). The food sources of iron reported (primarily meats) suggest that there may be little concern 
for lack of bioavailability. Yet reported anemia suggests inadequate iron intakes for adult Cree women as a group.

For calcium, $60 \%$ of women did not attain $2 / 3$ RNI, a possible indication that an important proportion of women may be at risk for inadequate calcium intakes. Moreover, few food sources of calcium were reported on the recalls. This concern has been expressed in other dietary studies with northern aboriginal women (Sevenhuysen and BogertO’Brien, 1987; Wein et al., 1991, 1993; Campbell et al., 1994a; Kuhnlein et al., 1995; Wein, 1995). Traditional northern aboriginal food sources of calcium are dried fish with small bones and skin and soups or stews simmered with bones (Campbell et al., 1994a; Kuhnlein et al., 1995) These foods are consumed in the present Cree diet, but not in the amounts needed for favorable calcium intake levels. In this study, smoked whitefish and fresh whitefish (both traditional foods) were consumed relatively often, yet they provided only $5.2 \%$ of reported calcium intakes.

Comparisons of individual reported intakes to RNIs cannot determine inadequate or deficient nutrient intakes of a population group. These analyses were based on single recalls from two seasons. A clearer dietary evaluation could be derived if we had many recalls from each interviewee to compare to the RNIs.

Any inquiry concerned about total fat intake, specifically excess dietary fat, must examine the sources of fat in the diet. In this study a relatively small proportion of total fat can be attributed to traditional food sources; overall, market foods were the greatest contributors. The top market food sources of fat were present consistently in both seasons.

The mean intakes of fat from market and traditional foods had to be determined from small groups of women, since few recalls included both traditional and market foods for each age group in each season. Ideally, mean intakes should be determined from more than 25 recalls. However these analyses, used along with other sources of dietary information, allow for meaningful if cautious interpretations.

In summer, Canada goose was the top contributor of total fat for all women. However, the fatty acid profile of this traditional food has not been determined and, like other wild foods, it may contribute favorable ratios of polyunsaturated to saturated fatty acids (Appavoo et al., 1991). Until nutrient composition data for Cree traditional foods are better established, the known and potential benefits of these foods must be considered against the potential risks (for example high total fat) of consuming them. Efforts to reduce total dietary fat intake should focus on market sources, which are generally nutrient-poor.

Seasonal differences in traditional food use were evident in both the 24-hour recall data, which reflected a summer month and a winter month, and the food frequency questionnaire, which covered three-month periods in spring and fall. Dietary studies on traditional food use cannot ignore the influence of seasons on the amounts and types of traditional food used. In this study, interviews were conducted in seasons of varied food use, as suggested by community members, precisely to gain an appreciation of the differences. Other dietary studies with aboriginal peoples in the North have demonstrated that use of traditional food varies by season (Wein et al., 1991; Kuhnlein et al., 1995, 1996).

The trend observed-that greater numbers of older women consume traditional food-could be evidence of diet in transition. Elders are described as needing traditional food to maintain their health; but this is also the food they grew up on and prefer to eat. Although food preferences were not studied here, it was clear that almost everyone appreciates traditional food. The greater availability of traditional food to elders may explain why more older women than younger women reported eating it.

\section{CONCLUSION}

This first study to describe the nutrient intakes and food sources of the current Cree diet found that it is affected by season and that women's diets vary from age group to age group. Information about the current diet and food consumption patterns of the Cree is needed to assist in addressing health and other concerns. This research has direct relevance for the James Bay Cree and will also contribute to our understanding of how changing diet affects the patterns of health and disease among other aboriginal groups.

\section{REFERENCES}

ANDERSON, S.A. 1986. Guidelines for use of dietary intake data. Bethesda, Maryland: Life Sciences Research Office, Federation of American Societies for Experimental Biology.

APPAVOO, D.M., KUBOW, S., and KUHNLEIN, H.V. 1991. Lipid composition of indigenous foods eaten by Sahtú (Hareskin) Dene-Metis of the Northwest Territories. Journal of Food Composition Analysis 4:107-119.

BERNARD, L., and LAVALLÉE, C. 1993. Eating habits of Cree schoolchildren: A pilot study. Montreal, Quebec: Community Health Department, Montreal General Hospital.

BERNARD, L., LAVALLÉE, C., GRAY-DONALD, K., and DELISLE, H. 1995. Overweight in Cree schoolchildren and adolescents associated with diet, low physical activity, and high television viewing. Journal of the American Dietetic Association 95:800-802.

BINGHAM, S.A., and NELSON, M. 1991. Assessment of food consumption and nutrient intake. In: Margetts, B.M., and Nelson, M., eds. Design concepts in nutritional epidemiology. New York: Oxford University Press.

BLACK, A.E., PRENTICE, A.M., GOLDBERG, G.R., JEBB, S.A., BINGHAM, S.A., LIVINGSTONE, B.E., and COWARD, W.A. 1993. Measurements of total energy expenditure provide insights into the validity of dietary measures of energy intake. Journal of the American Dietetic Association 93(5):572-579. 
CAMPBELL, M. L., DIAMANT, R.M.F., MACPHERSON, B.D., GRUNAU, M., and HALLADAY, J. 1994a. Energy and nutrient intakes of men (56-74 years) and women (16-74) in three northern Manitoba Cree communities. Journal of the Canadian Dietetic Association 55(4):167-174.

CAMPBELL, M.L., DIAMANT, R., MARGARET, G., and HALLADAY, J. 1994b. Surveys in Aboriginal communities: Methodological considerations. Canadian Home Economics Journal 44(3):118-122.

DAVEluY, C., LAVAlleÉ, C., ClARKSON, M., and ROBINSON, E. 1994. A health profile of the Cree: Report of the Santé Québec Health Survey of the James Bay Cree 1991. Ministère de la Santé et des Services Sociaux, Government of Quebec.

DEAN, A.G., DEAN, J.A., COULOMBIER, D., BRENDEL, K.A., SMITH, D.C., BURTON, A.H., DICKER, R.C., SULLIVAN, K., FAGAN, R.F., and ARNER, T.G. 1994. Epi-Info, Version 6: A word-processing, database, and statistics program for epidemiology on microcomputers. Atlanta, Georgia: Centers for Disease Control and Prevention.

DELORMIER, T. 1993. Traditional food of the James Bay Cree: Observations from Chisasibi and Mistissini for summer 1992. Unpubl. report. Available at the Centre for Indigenous Peoples' Nutrition and Environment, Macdonald Campus of McGill University, 21111 Lakeshore Road, Ste. Anne de Bellevue, Quebec H9X 3V9, Canada.

FARKAS, C.S., and BERKES, F. 1978. Eastern James Bay Cree Indians: Changing patterns of wild food use and nutrition. Ecology of Food and Nutrition 7:155-172.

GIBSON, R.S. 1990. Principles of nutritional assessment. New York: Oxford University Press.

HEALTH AND WELFARE CANADA. 1990. Nutrition recommendations: The report of the Scientific Review Committee. Ottawa: Minister of Supply and Services Canada.

JAMES BAY AND NORTHERN QUEBEC NATIVE HARVESTING RESEARCH COMMITTEE. 1982. The wealth of the land: Wildlife harvests by the James Bay Cree, 1972-73 to 1978-79. Quebec City: James Bay and Northern Quebec Native Harvesting Research Committee.

KUHNLEIN, H.V. 1995. Benefits and risks of traditional food for Indigenous Peoples: Focus on dietary intakes of Arctic men. Canadian Journal of Physiology and Pharmacology 73:765771.

KUHNLEIN, H.V., RECEVEUR, O., MORRISON, N.E., APPAVOO, D.M., SOUEIDA, R., and PIERROT, P. 1995. Dietary nutrients of Sahtú Dene/Métis vary by food source, season and age. Ecology of Food and Nutrition 34:183-195.
KUHNLEIN, H.V., SOUEIDA, R., and RECEVEUR, O. 1996. Dietary nutrient profiles of Canadian Baffin Island Inuit differ by food source, season, and age. Journal of the American Dietetic Association 92:2:155-162.

McDOWELL, M.A., BRIEFEL, R.R., ALAIMO, K., BISCHOF, A., CAUGHMAN, C.R., CARROLL, M.D., LORIA, C.M., and JOHNSON, C.L. 1994. Energy and macronutrient intakes of persons ages 2 months and over in the United States: Third National Health and Nutrition Examination Survey, phase 1, 1988-91. Advance Data 255:1-25.

MERTZ, W., TSUI, J.C., JUDD, J.T., REISER, S., HALLFRISCH, J., MORRIS, E.R., STEELE, P.D., and LASHLEY, E. 1991. What are people really eating? The relation between energy intake derived from estimated diet records and intake determined to maintain body weight. American Journal of Clinical Nutrition 54:291-295.

MURPHY, S.P., and GROSS, K.R. 1989. The UCB MiniList Diet Analysis System. MS-DOS Version User's Guide (Revised June 1987). Berkeley, California: The Regents of the University of California.

SAS INSTITUTE INC. 1989. Statistical Analysis Systems for Personal Computers, Version 6.03. SAS/STAT Guide for Personal Computers. 6th ed. Cary, North Carolina: SAS Institute Inc.

SCHAEFER, O. 1977. Changing dietary patterns in the Canadian North: Health, social and economic consequences. Journal of the Canadian Dietetic Association 38(1):17-25.

SEVENHUYSEN, P., and BOGERT-O'BRIEN, L.A. 1987. Nutrient intake of women and school children in northern Manitoba Native communities. Journal of the Canadian Dietetic Association 48(2):89-94.

THOUEZ, J.P., RANNOU, A., and FOGGIN, P. 1989. The other face of development: Native population, health status and indicators of malnutrition - The case of the Cree and Inuit of Northern Quebec. Social Science and Medicine 29(8):965974.

WEIN, E.E. 1995. Nutrient intakes of First Nations peoples in four Yukon communities. Nutrition Research 15(8):11051119.

WEIN, E.E., SABRY, J.H., and EVERS, F.T. 1991. Nutrient intakes of Native Canadians near Wood Buffalo National Park. Nutrition Research 11:5-13.

WEIN, E.E., GEE, M.I., and HAWRYSH, Z.J. 1993. Nutrient intakes of Native mothers and school children in northern Alberta. Journal of the Canadian Dietetic Association 54(1):42 47.

YOUNG, T.K. 1994. The health of Native Americans: Towards a biocultural epidemiology. New York: Oxford University Press. 